\title{
Evaluation Of The Growth Performance Of Trichoderma harzianum (Rifai.) On Different Culture Media
}

\author{
Nusrat Jahan ${ }^{1}$, Sabiha Sultana ${ }^{2}$, S. K Adhikary ${ }^{3}$, Sanzida Rahman ${ }^{4}$, \\ Suraiya Yasmin ${ }^{5}$ \\ $(1,4,5=$ Ex-student, 2 = Assistant professor, $3=$ professor Agrotechnology discipline, Khulna University $)$
}

\begin{abstract}
To evaluate the growth of Trichoderma harzianum on different culture media namely, potato dextrose agar, modified potato dextrose agar, water agar, carrot agar and cornmeal agar. Linear growth was recorded at 24 hours intervals after inoculation and average growth rates were calculated. Fresh weight and dry weight were also recorded. The highest linear growth, fresh weight and dry weight were found in potato dextrose agar and lowest in water agar. The highest values were followed by modified potato dextrose agar which was statistically similar to carrot agar which was differed and followed by cornmeal agar.

Key word: growth performance, Trichoderma harzianum, different culture media

Corresponding author: Sabiha sultana, Assistant professor, Agrotechnology discipline, Khulna University, Bangladesh-9208
\end{abstract}

\section{Introduction}

Biological control involves the use of biological organisms to control pathogens or diseases. The microbial inoculants as biocontrol agents are effective and attractive alternatives to prevent the deficiencies brought about by the exclusive reliance on chemicals (Nakkeeran et al., 2002). Members of Trichoderma particularly $T$. harzianum are promising biological control agents (bioprotectants) against plant diseases. Trichoderma are free-living fungi and common in soil and root ecosystems. They are opportunistic, avirulent plant symbionts, as well as being parasites of other fungi (Harman et al., 2004). These filamentous fungi are very wide spread in nature, with high population densities in soils and plant litters. They are saprophytic, quickly growing and easy to culture and they can produce large amount of conidia with long shelflife. $T$. harzianum is environmentally safe to control plant pathogen compared to any other pesticides. Farmers can easily use this antagonistic pathogen commercially to increase their yield of crop and decrease the using cost of pesticides (http://thiqaruni.org/engpdf9/42.pdf). Among the different bio-control agents so far identified, species of Trichoderma are the most effective in reducing disease incidence of various crops.

Biomass used for biological control must be inexpensive to produce. It should be capable of being dried with retention of a high level of germinable propagules, be insensitive to environmental fluctuations (e.g., temperature and humidity) and possess a long shelf life. Studies were conducted for the use of various culture media for growth of T. harzianum (Elad et al. 1981 and Harman et al. 1990; 1991).The minimal media Czapek Dox and Richard's medium supported a high level of conidial production of T. harzianum, but that overall yields were low. The addition of V8 juice to these media increased yields by 8 - to 16-fold, but only 1 to $10 \%$ of the conidia produced was viable after vacuum drying (G.E. Harman et al., 1991).

To use this antagonist (T. harzianum ) commercially, it is necessary to produce the maximum biomass with least economic cost. So, it is important to search suitable and cheap media for growth of $T$. harzianum. Considering the above facts, the present investigation was undertaken to evaluate the growth performance of $T$. harzianum on different culture media

\section{Materials And Methods}

An experiment was conducted in the Plant Protection Laboratory of Agrotechnology Discipline, Khulna University, to evaluate the performance of different media for growth of T. harzianum.

An isolate of T. harzianum was collected from the preserved isolates of Bangladesh Agricultural research Institute (BARI), Joydebpur, Gazipur.

PDA was prepared following the standard procedure (Anonymous, 1968). After preparation of media, $\mathrm{pH}$ of the medium was adjusted to 6.00 by adding $1 \% \mathrm{HCl}$ using $\mathrm{pH}$ meter. After melting the prepared medium was sterilized in an autoclave at $121^{\circ} \mathrm{C}$ temperature for 20 minutes.

\section{For the Multiplication of $T$. harzianum}

PDA medium was poured in sterilized petridishes, $20 \mathrm{ml}$ in each. A $5 \mathrm{~mm}$ block of the 3 days old pure culture of $T$. harzianum was placed upside down at the center of each plate. The block was cut with the help of a 
flame sterilized cork borer (5mm diameter). The inoculated petridishes were kept in the growth chamber at $27 \pm 2^{\circ} \mathrm{C}$ temperature. All the works were done under aseptic condition.

\section{For the Preservation of T. harzianum}

Sterilized PDA medium were poured into sterilized test tubes, $10 \mathrm{ml}$ in each. Then the test tubes were sterilized in an autoclave at $121^{\circ} \mathrm{C}$ temperature for 20 minutes. After autoclaving, slanting of test tube was done at $45^{\circ}$ angles to increase the surface area of the medium in the test tube. 7 days old fungal hyphae with the help of a inoculation niddle were placed in the test tube. After inoculation test tubes were kept in the growth chamber at $27 \pm 2^{\circ} \mathrm{C}$ temperature.

\section{Preparation of Different Media \\ Potato Dextrose Agar (PDA)}

PDA was prepared following the standard procedure (Anonymous, 1968) and the $\mathrm{pH}$ was adjusted to 6.00 using $\mathrm{pH}$ meter with the help of $1 \% \mathrm{HCl}$. The medium was then sterilized in an autoclave at $121^{\circ} \mathrm{C}$ temperature for 20 minutes.

\section{Modified Potato Dextrose Agar (MPDA)}

Modified PDA was prepared by using $125 \mathrm{gm}$ potato and $15 \mathrm{gm}$ dextrose instead of $200 \mathrm{~g}$ potato and $20 \mathrm{~g}$ dextrose respectively. The $\mathrm{pH}$ of the medium was adjusted to 6.00 using $\mathrm{pH}$ meter with the help of $1 \% \mathrm{HCl}$. The medium was then sterilized in an autoclave at $121^{\circ} \mathrm{C}$ temperature for 20 minutes.

\section{Water Agar (WA)}

Water agar was prepared following the standard procedure (Anonymous, 1968). 1000ml distilled water was boiled at first. After boiling it was poured into a beaker. The beaker is then placed on a heater with magnetic stirrer to mix $15 \mathrm{~g}$ agar and then adjusted to $1000 \mathrm{ml}$ by distilled water. The $\mathrm{pH}$ of the medium was adjusted to 6.00 using $\mathrm{pH}$ meter with the help of $1 \% \mathrm{HCl}$. The medium was then sterilized in an autoclave at $121^{\circ} \mathrm{C}$ temperature for 20 minutes.

\section{Carrot agar (CA)}

$400 \mathrm{~g}$ carrot was cut into slice and boiled in $1000 \mathrm{ml}$ distilled water. After boiling it was sieved into a beaker. The beaker is then placed on a heater with magnetic stirrer to mix $20 \mathrm{~g}$ agar and then adjusted to $1000 \mathrm{ml}$ by distilled water. The $\mathrm{pH}$ of the medium was adjusted to $6.00 \mathrm{using} \mathrm{pH}$ meter with the help of $1 \% \mathrm{HCl}$. The medium was then sterilized in an autoclave at $121^{\circ} \mathrm{C}$ temperature for 20 minutes.

\section{Cornmeal agar (CMA)}

$20 \mathrm{~g}$ cornmeal was weighted on an electric balance and mixed with $1000 \mathrm{ml}$ boiling water slowly. After mixing, it was sieved into a beaker. The beaker is then placed on a heater with magnetic stirrer to mix $15 \mathrm{~g}$ agar and then adjusted to $1000 \mathrm{ml}$ by distilled water. The $\mathrm{pH}$ of the medium was adjusted to 6.00 using $\mathrm{pH}$ meter with the help of $1 \% \mathrm{HCl}$. The medium was then sterilized in an autoclave at $121^{\circ} \mathrm{C}$ temperature for 20 minutes.

\section{Pouring of Media}

In all cases of media $20 \mathrm{ml}$ medium was poured in each petridish. where as five plates for each medium.

\section{Inoculation and Incubation}

Advanced hyphae of 3 days old culture was used for inoculation. A $5 \mathrm{~mm}$ block of the mycelium was cut with flame sterilized cork borer $(5 \mathrm{~mm})$. The mycelial blocks were taken from the edge of the colony. Each mycelial block was placed upside down at the centre of each plate. Five replicated plates were used for each medium. The inoculated petridishes were kept in the growth chamber at room temperature $\left(27 \pm 2^{\circ} \mathrm{C}\right)$ and $90 \%$ relative humidity $(\mathrm{RH})$ until the mycelia touch the edge of petridishes.

\section{Measurement of Average Linear Growth Rate (ALGR) of T. harzianum on Different Growth Media}

After 3 days of incubation, linear growth (mm) of T. harzianum was recorded. Linear growth measured by averaging three diameters taken from each colony.

Average linear growth rate was measured by the following formula (Aneja, 1993 and Elad et al., 1981).

$$
\operatorname{ALGR}(\mathrm{mm} / \mathrm{day})=(\mathrm{C} 3-\mathrm{C} 0) / 3
$$

Where $\mathrm{C} 3=$ Colony diameter after 3 days of inoculation

$\mathrm{C} 0=$ Initial colony diameter of inoculation 


\section{Colony Characteristics of $T$. harzianum}

After 4 days of incubation, different colony characters such as surface, color, margin, texture and hyphal thickness was observed visually in each different media.

\section{Measurement of Fresh Weight and Dry Weight of T. harzianum on different media}

For the measurement of fresh weight and dry weight of T. harzianum was grown in $100 \mathrm{ml}$ of potato dextrose broth (PDB), modified potato dextrose broth (MPDB), water broth (WB), carrot broth (CB), cornmeal broth $(\mathrm{CMB})$ in $250 \mathrm{ml}$ conical flask. These media were inoculated with $5 \mathrm{~mm}$ block of 3 days old culture of $T$. harzianum grown on PDA. The inoculated conical flasks were kept in the growth chamber at $27 \pm 2^{\circ} \mathrm{C}$ temperature and $90 \% \mathrm{RH}$. The conical flasks were shaked at 24 hours of interval till 14 days of inoculation to inhibit colony formation on the surface of growth. After 14 days inoculation the fungal mass in each conical flask was separated by filtration using Whatman paper No. 1. The filtrates were discarded and the fungal biomass on the filter paper was air dried at room temperature for 24 hours. Then the fresh weight $(\mathrm{mg} / 100 \mathrm{ml})$ was measured with electric balance. The fungal biomass of all treatments was oven dried at $70^{\circ} \mathrm{C}$ temperature for 72 hours. Then the oven dried fungal biomass was weighted $(\mathrm{mg} / 100 \mathrm{ml})$ to have the dry weight.

\section{Experimental Design and Data Analysis}

Experimental Design was Completely Randomized Design (CRD) with five replications and data was analyzed statistically using MSTAT-C computer program and means were compared following Duncan's Multiple Range Test (DMRT).

\section{Result and Discussion}

\section{Average Linear Growth Rate (ALGR) of T. harzianum on Different Culture Media}

Average linear growth of T. harzianum on different tested media was varied significantly $(\mathrm{p}=0.01)$ (Table 1$)$. The growth rate was highest in PDA $(22.86 \mathrm{~mm} /$ day $)$ and lowest in water agar $(13.18 \mathrm{~mm} /$ day $)$. Higher linear growth on PDA was followed by MPDA medium $(20.29 \mathrm{~mm} /$ day $)$ and also differed significantly. Linear growth on MPDA was statistically similar with the growth on CA medium $(18.95 \mathrm{~mm} /$ day $)$. Linear growth on CMA medium $(16.53 \mathrm{~mm} /$ day) varied significantly from the linear growth on CA and WA medium.

Table 1. Average linear growth rate on different culture media

\begin{tabular}{lc}
\hline Growth medium & Average linear growth rate (mm/day) \\
\hline Potato dextrose agar & $22.86 \mathrm{a}$ \\
Modified potato dextrose agar & $20.29 \mathrm{~b}$ \\
Carrot agar & $18.95 \mathrm{~b}$ \\
Cornmeal agar & $16.53 \mathrm{c}$ \\
Water agar & $13.18 \mathrm{~d}$ \\
CV $(\%)$ & $3.38 \%$ \\
Level of significance & 0.01 \\
\hline
\end{tabular}

Azher Mustafa and co-workers (2009) studied the growth of Trichoderma spp. on five semi synthetic media including PDA and found PDA as the best medium. Das and co-workers (1997) also studied growth of Trichoderma spp. on PDA and four other natural media and found wheat bran as the best.

\section{Linear Growth of T. harzianum on Different Culture Media}

From the initial day of inoculation to 3 days after inoculation the growth of $T$. harzianum on different culture media is shown in figure 1. At the first day the highest growth was found in potato dextrose agar and the lowest was obtained from water agar medium. In the $2^{\text {nd }}$ day the maximum growth was obtained in potato dextrose agar and minimum growth was obtained in water agar medium. At the $3^{\text {rd }}$ day the maximum growth was found in potato dextrose agar medium and minimum growth was found in water agar medium. Growth of $T$. harzianum was consistent on all media from first day to third day except MPDA. Growth of $T$. harzianum on MPDA was above to WA in the first day but it was next to PDA in the third day. 


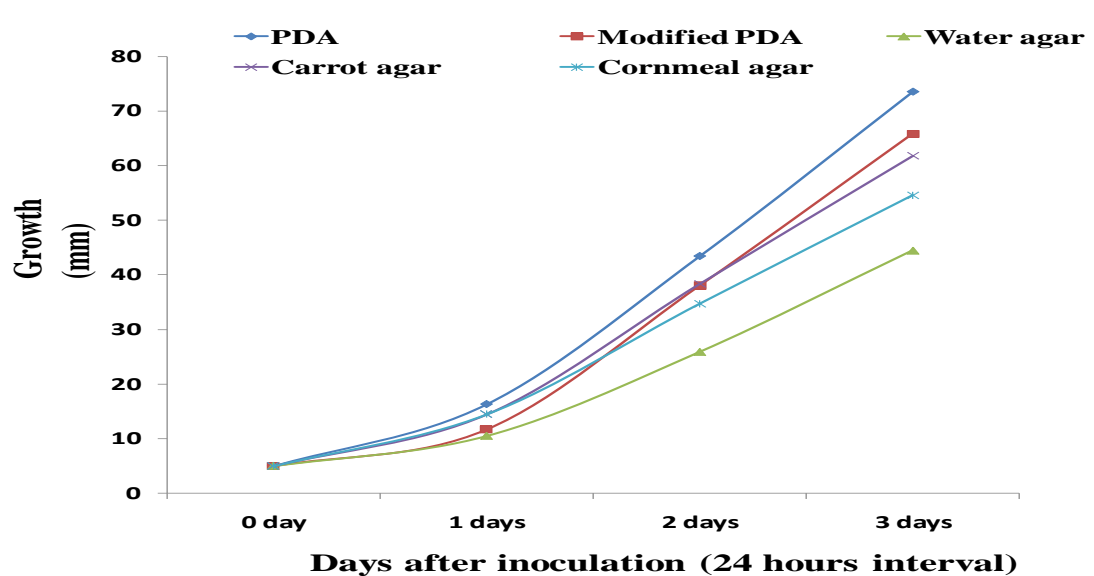

Figure 1: Linear Growth of $T$. harzianum from initial days of inoculation to 3 days after inoculation

\section{Colony Characteristics of T. harzianum on Different Culture Media}

Colony characteristics of $T$. harzianum on different culture media is shown on table 2 . There exists no difference in color of the upper and lower surfaces of T. harzianum in all of the five media (plate 1, plate 2, plate 3 , plate 4 , and plate 5). The colony margin of all the media was regular. A few variations were observed in colony texture, moderately compact colony texture was found in potato dextrose agar (Plate 1) while loose and puffy colony texture was found in modified potato dextrose agar and cornmeal agar medium (Plate 2, plate 5). Water agar medium had a loose colony texture (Plate 5), whereas compact colony texture was found in carrot agar medium (Plate 3). In the case of hyphal thickness some variations were observed, thick hyphal thickness was found in the case of potato dextrose agar medium (Plate 1) and moderately thick hyphal thickness was found in the case of modified potato dextrose agar, carrot agar and cornmeal agar medium (Plate 2, plate 3, plate 4) and very thin hyphal thickness was found in water agar medium (Plate 5).

Table 2. Colony Characteristics of $T$. harzianum on different media

\begin{tabular}{|c|c|c|c|c|c|}
\hline Growth Media & Surface & Color & Margin & Texture & $\begin{array}{l}\text { Hyphal } \\
\text { thickness }\end{array}$ \\
\hline \multirow{2}{*}{$\begin{array}{l}\text { Potato dextrose } \\
\text { agar (PDA) }\end{array}$} & Upper & White & \multirow[t]{2}{*}{ Regular } & \multirow{2}{*}{$\begin{array}{l}\text { Moderately } \\
\text { compact }\end{array}$} & \multirow[t]{2}{*}{ Thick } \\
\hline & Lower & White & & & \\
\hline \multirow{2}{*}{$\begin{array}{ll}\text { Modified } & \text { Potato } \\
\text { dextrose } & \text { agar } \\
\text { (MPDA) } & \end{array}$} & Upper & White & \multirow[t]{2}{*}{ Regular } & \multirow[t]{2}{*}{ Loose, puffy } & \multirow{2}{*}{$\begin{array}{l}\text { Moderately } \\
\text { thick }\end{array}$} \\
\hline & Lower & White & & & \\
\hline \multirow{2}{*}{$\begin{array}{l}\text { Carrot agar } \\
\text { (CA) }\end{array}$} & Upper & White & \multirow[t]{2}{*}{ Regular } & \multirow[t]{2}{*}{ Compact } & \multirow{2}{*}{$\begin{array}{l}\text { Moderately } \\
\text { thick }\end{array}$} \\
\hline & Lower & White & & & \\
\hline \multirow{2}{*}{$\begin{array}{l}\text { Cornmeal agar } \\
\text { (CMA) }\end{array}$} & Upper & White & \multirow[t]{2}{*}{ Regular } & \multirow[t]{2}{*}{ Loose, puffy } & \multirow{2}{*}{$\begin{array}{l}\text { Moderately } \\
\text { thick }\end{array}$} \\
\hline & Lower & White & & & \\
\hline \multirow{2}{*}{$\begin{array}{l}\text { Water agar } \\
\text { (WA) }\end{array}$} & Upper & White & \multirow[t]{2}{*}{ Regular } & \multirow[t]{2}{*}{ Loose } & \multirow[t]{2}{*}{ Very thin } \\
\hline & Lower & White & & & \\
\hline
\end{tabular}
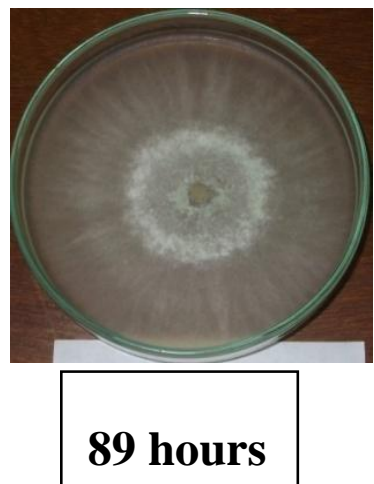

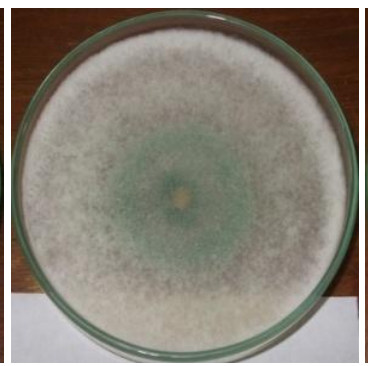

113 hours
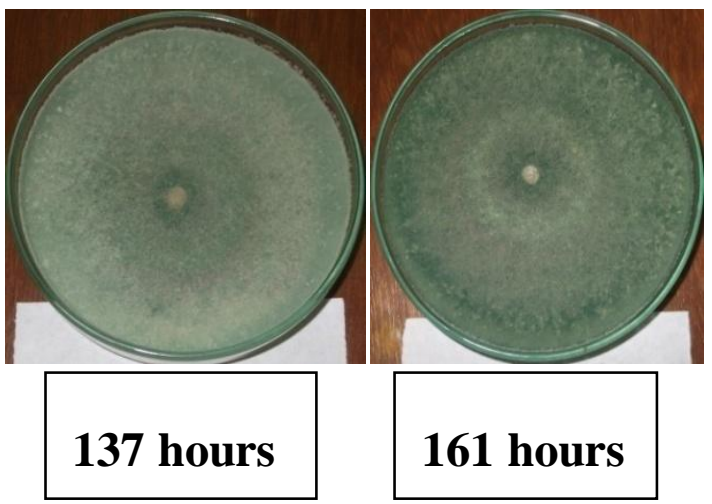

Plate 1: Images of T. harzianum in PDA at 24hours of interval after 3 days of inoculation 

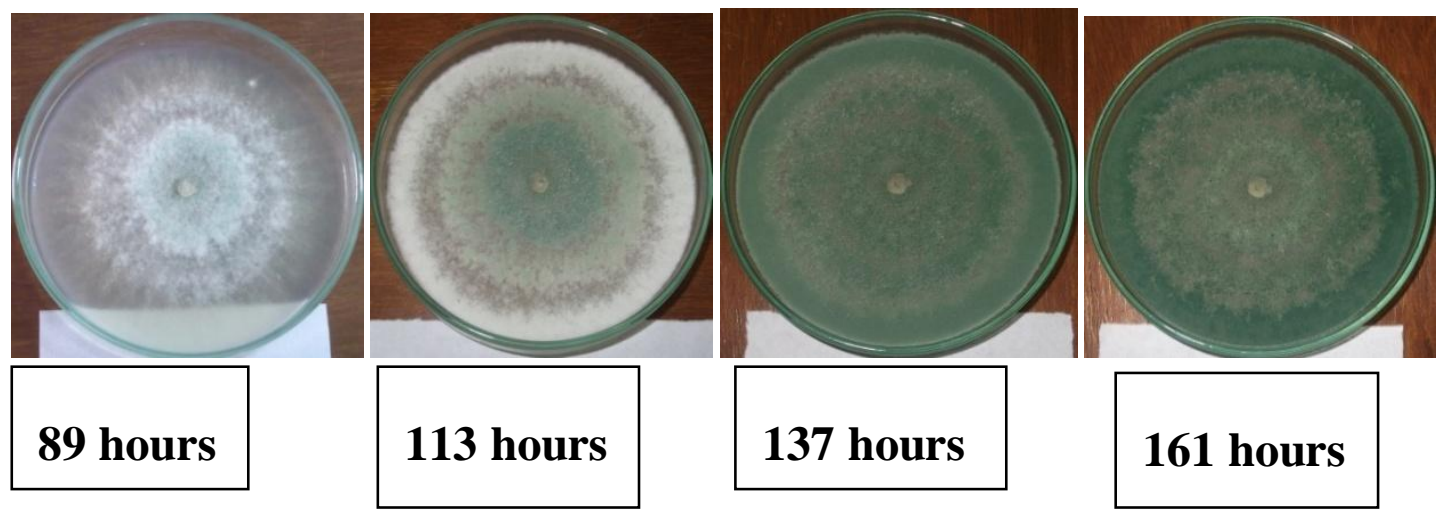

Plate 2: Images of $T$. harzianum in MPDA at 24hours of interval after 3 days of inoculation
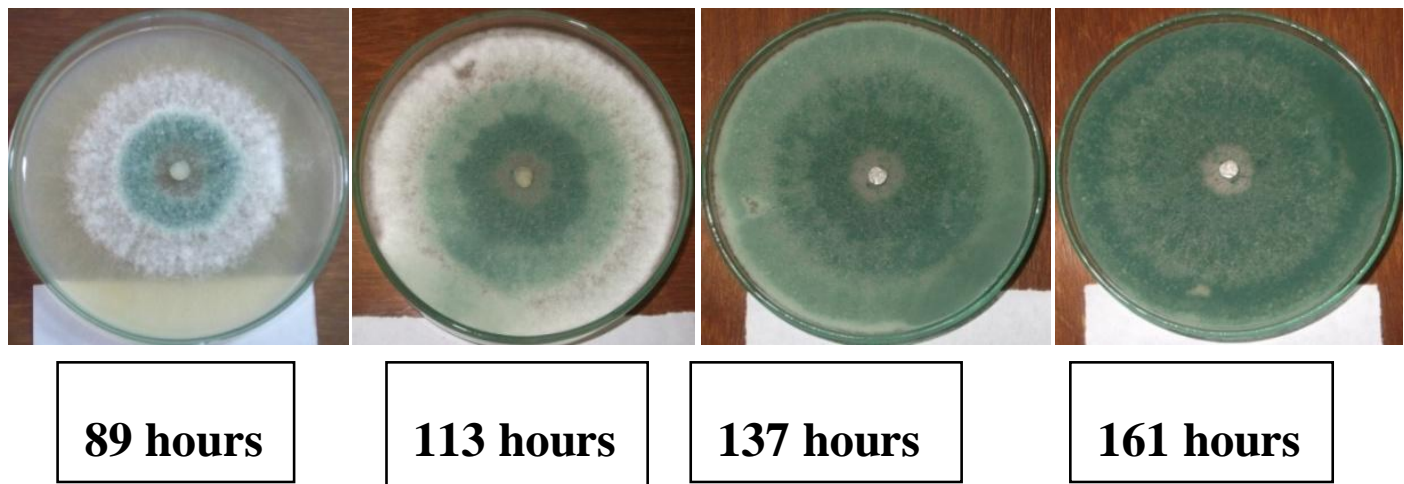

\section{1 hours}

Plate 3: Images of $T$. harzianum in CA at 24hours of interval after 3 days of inoculation

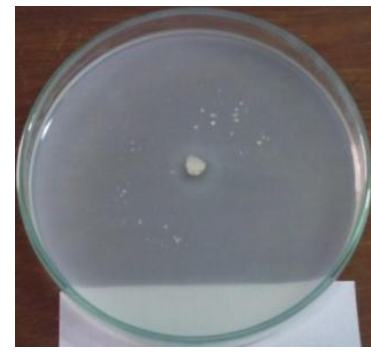

89 hours

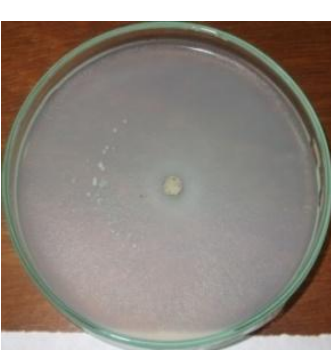

113 hours

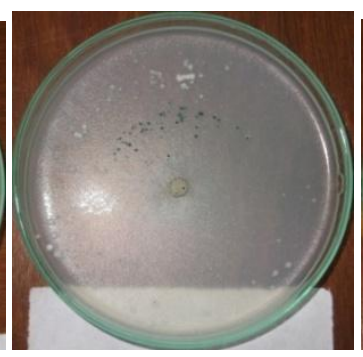

137 hours

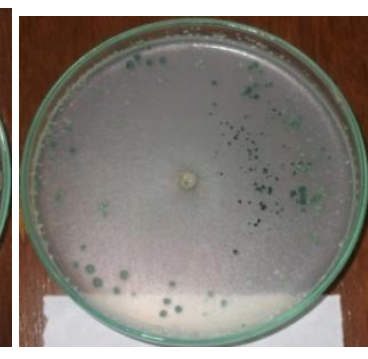

161 hours

Plate 4: Images of T. harzianum in CMA at 24hours of interval after 3 days of inoculation
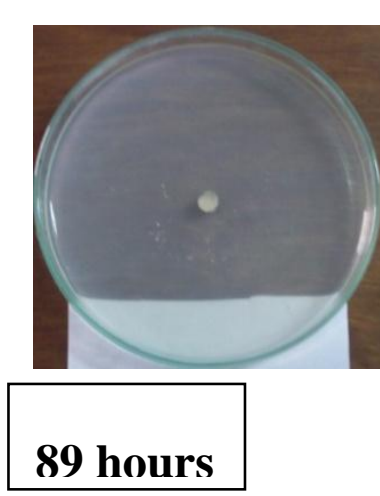
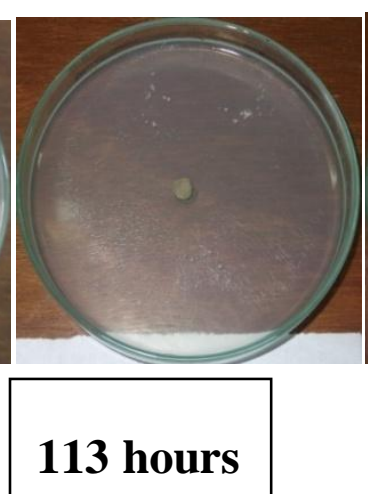
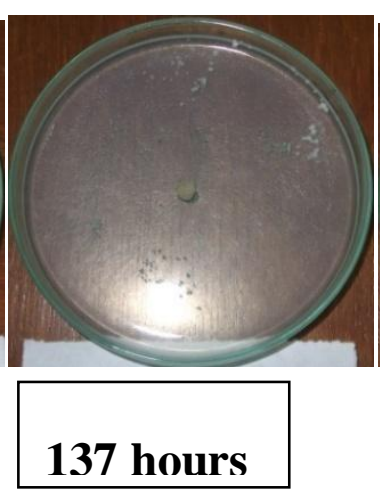

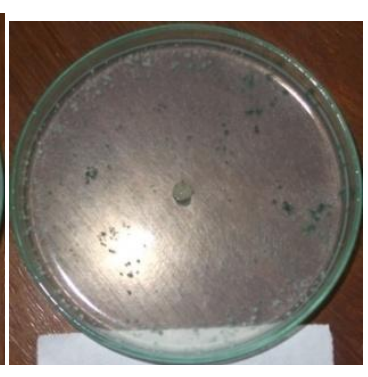

161 hours

Plate 5: Images of $T$. harzianum in WA at 24hours of interval after 3 days of inoculation Biomass of $T$. harzianum on five Culture Media 


\section{Fresh weight}

Fresh weight of $T$. harzianum on different tested media varied significantly ( $\mathrm{p}=0.01$ ) (Table 3 ). The fresh weight was highest in PDB $(637.00 \mathrm{mg})$ and lowest in WA $(6.60 \mathrm{mg})$. Highest fresh weight on PDB was followed by MPDB (484.20 mg) and also differed significantly. Fresh weight on MPDB was statistically similar with the weight on CMB (469.00 mg).Fresh weight on CB $(251.20 \mathrm{mg})$ varied significantly from the fresh on $\mathrm{CMB}$ and WB.

\section{Dry weight}

Dry weight of $T$. harzianum on different tested media varied significantly $(\mathrm{p}=0.01)$ (Table 3$)$. The dry weight was highest in PDB (627.00 mg) and lowest in water agar (3.00 mg). Highest fresh weight on PDB was followed by MPDB (476.00 mg) and also differed significantly. Fresh weight on MPDB was statistically similar with the weight on CMB (465.40 mg).Fresh weight on CB (242.60 mg) varied significantly from the fresh on $\mathrm{CMB}$ and $\mathrm{WB}$.

Table 3. Fresh Weight and Dry Weight of T. harzianum on different media

\begin{tabular}{lcc}
\hline Growth medium & Fresh Weight (mg) & Dry Weight (mg) \\
\hline Potato dextrose broth & $637.00 \mathrm{a}$ & $627.00 \mathrm{a}$ \\
Modified potato dextrose broth & $484.20 \mathrm{~b}$ & $476.00 \mathrm{~b}$ \\
Cornmeal broth & $469.00 \mathrm{~b}$ & $465.40 \mathrm{~b}$ \\
Carrot broth & $251.20 \mathrm{c}$ & $242.60 \mathrm{c}$ \\
Water broth & $6.60 \mathrm{~d}$ & $3.00 \mathrm{~d}$ \\
CV $(\%)$ & 2.00 & 1.79 \\
Level of signicance & 0.01 & 0.01 \\
\hline
\end{tabular}

Azher Mustafa and co-workers (2009) studied the biomass of Trichoderma spp. on five semi synthetic media including PDA and found PDA as the best medium. Das and co-workers (1997) also studied biomass of Trichoderma spp. on PDA and four other natural media and found wheat bran as the best.

Fresh weight and dry weight of $T$. harzianum on different media were found consistent to linear growth of the fungus except cornmeal broth and carrot broth media. Linear growth was higher in carrot agar than cornmeal agar but fresh weight and dry weight were higher in cornmeal agar than carrot agar. In cornmeal agar texture was puffy indicating less linear growth but more aerial growth that might corresponds to the more biomass.

\section{Conclusion}

Potato dextrose agar was found more effective and water agar was found less effective for average linear growth rate of $T$. harzianum and Maximum biomass of $T$. harzianum was produced in potato dextrose broth and the minimum was produced in water broth.

\section{References}

[1]. Agosin E., D. Volpe, G. Munoz, R. San Martin and A. Crawford. 1997. Effect of culture conditions on spore shelf life of biocontrol agent Trichoderma harzianum. World Journal of Microbiology and Biotechnology. 13(2): 225-232.

[2]. Anonymous, 1968. Plant Pathologist's Pocket Book. Commonwealth Mycological Institute, Pp: $394-395$.

[3]. Azher Mustafa, M. Aslam Khan, M. Inam-ul-Haq, M. Aslam Pervez and Ummad- ud-DinUmar. 2009. Usefulness of different culture media for in-vitro evaluation of Trichoderma spp. Against seed-borne fungi of economic importance. Pak. J.Phytopathol., 21(1): 8388 .

[4]. Chaudhari1 P. J., Prashant Shrivastava, A. C. Khadse. 2011. Substrate Evaluation for mass cultivation of Trichoderma viride. Asiatic Journal of Biotechnology Resource; 2(04): 441-446.

[5]. Das, B. C., S. K. Roy and L. C. Boro. 1997. Mass multiplication of Trichoderma species on different media. Ind. J. Agri. Sci., 10(1): 95-100.

[6]. Dilip K. Arora, Paul D. Bridge, Deepak Bhatnagar. 2003. Fungal Biotechnology in Agricultural, Food, and Environmental Applications.

[7]. Elad Y. and B. Kirshner. 1993.Survival in the phylloplane of an introduced Biocontrol agent (Trichoderma harzianum) and populations of the plant pathogen Botrytis cinerea as modified by abiotic conditions. Phytoparasitica, 21, (4): 303-313.

[8]. Elad, Y., I. Chet and Y. Henis. 1981. A selective medium for improving quantitative isolation of Trichoderma spp. From soil. Phytoparasitica, 9(1): 59-69.

[9]. Fernandez Sandoval M.T., M. Ortiz Garcia, E. Galindo, L. Serrano Carreon. 2012. Cellular damage during drying and storage of Trichoderma harzianum spores. Process Biochemistry, 47: 186-194.

[10]. Harman, G. E., C. R. Howell, A. Viterbo, I. Chet and M. Lorito. 2004. Trichoderma species- opportunistic, avirulent plant symbionts, Nat. Rev. Microbial, 2 (1): 43-56.

[11]. Harman, G.E., X. Jin, T.E. Stasz, G. Peruzzotti, A.C. Leopold, A.G. Taylor.1991. Production of conidial biomass of Trichodermaharzianum for biological control. Biological Control, 1:23-28. 
[12]. Harman, G. E., X. Jin, T. E. Stasz, G. Peruzzotti, A. C. Leopold and A. G. Taylor. 1990. Development of media to produce conidial biomass of Trichoderma harzianum for biological control. Phytopathology: 80-992.

[13]. Nakkeeran, S., A. S. Krishnamoorthy, V. Ramamoorthy and P. Renukadevi. 2002. Microbial inoculants in plant disease control. J. Ecobiol., 14(2): 83-94.

[14]. Pramod kumar T. and M. G. Palakshappa. 2009. Evaluation of suitable substrates for on farm production of antagonist Trichoderma harzianum. Karnataka J. Agric. Sci., 22(1): 115-117.

[15]. Rini C.R. and K.K. Sulochana. 2007. Substrate evaluation for multiplication of Trichoderma spp. Department of Plant Pathology, College of Agriculture, Kerala Agricultural University, Vellayani, Kerala, India.

[16]. Sebran and Noor Haida. 2008. Growth Requirement, Mass Production and Application of Trichoderma harzianumas a Growth Enhancer of Oil Palm. Masters thesis, University Putra Malaysia.

[17]. Singh V., P. N. Singh, R. L. Yadav, S. K. Awasthi, B. B. Joshi, R. K. Singh, R. J. Lal and S. K. Duttamajumder. 2009. Increasing the efficacy of Trichoderma harzianum for nutrient uptake and control of red rot in sugarcan. Indian Institute of Sugarcane Research,Lucknow-226 002, U. P., India.

[18]. Singh A., Srivastava S., H.B. Singh. 2007. Effect of substrates on growth and shelf life of Trichoderma harzianum and its use in biocontrol of diseases. Biosource technology. 98: 470-473.

[19]. Sobita Simon and Anamika. 2011. Agro-based Waste Products as a Substrate for Mass Production of Trichoderma spp. Journal of Agricultural Science Vol. 3, No. 4

[20]. Thangavelu R., A. Palaniswami, R. Velazhahan. 2004. Mass production of Trichoderma harzianum for managing fusarium wilt of banana. Agriculture, Ecosystem \& Environment. 103: 259-263.

[21]. X Jin, G.E Harman, A.G Taylor.1991. Conidial biomass and desiccation tolerance of Trichoderma harzianum produced at different medium water potentials. Biological Control. 1: 237-243.

[22]. http://thiqaruni.org/engpdf9/42.pdf

[23]. http://ecisi.com/wp-content/uploads/2012/05/292-298.pdf.

[24]. http://prr.hec.gov.pk/Chapters/121S-2.pdf 